\title{
Overexpression of the antioxidant enzyme catalase does not interfere with the glucose responsiveness of insulin-secreting INS-1E cells and rat islets
}

\author{
S. Lortz • E. Gurgul-Convey $\cdot$ O. Naujok $\cdot$ S. Lenzen
}

Received: 7 June 2012 / Accepted: 12 December 2012 /Published online: 11 January 2013

(C) Springer-Verlag Berlin Heidelberg 2013

\begin{abstract}
Aims/hypothesis Hydrogen peroxide $\left(\mathrm{H}_{2} \mathrm{O}_{2}\right)$-inactivating enzymes such as catalase are produced in extraordinarily low levels in beta cells. Whether this low expression might be related to a signalling function of $\mathrm{H}_{2} \mathrm{O}_{2}$ within the beta cell is unknown. A high level of $\mathrm{H}_{2} \mathrm{O}_{2}$-inactivating enzymes could potentially be incompatible with glucose-induced insulin secretion. Therefore the effect of catalase overexpression on mitochondrial function and physiological insulin secretion was studied in insulin-secreting INS-1E and primary islet cells.

Methods INS-1E and rat islet cells were lentivirally transduced to overexpress catalase in the cytosol (CytoCat) or in mitochondria (MitoCat). Cell viability and caspase-3 activation were assessed after cytokine incubation and hypoxia. Insulin secretion was quantified and expression of the gene encoding the mitochondrial uncoupling protein 2 (Ucp2) was measured in parallel to mitochondrial membrane potential and reactive oxygen species (ROS) formation.

Results The ability to secret insulin in a glucose-dependent manner was not suppressed by catalase overexpression, although the glucose-dependent increase in the mitochondrial membrane potential was attenuated in MitoCat cells along with an increased Ucp 2 expression and reduced mitochondrial ROS formation. In addition, MitoCat overexpressing cells were significantly more resistant against pro-
\end{abstract}

Electronic supplementary material The online version of this article (doi:10.1007/s00125-012-2823-7) contains peer-reviewed but unedited supplementary material, which is available to authorised users.

S. Lortz $\cdot$ E. Gurgul-Convey $\cdot$ O. Naujok $\cdot$ S. Lenzen $(\bowtie)$ Institute of Clinical Biochemistry, Hannover Medical School, 30623 Hannover, Germany

e-mail: lenzen.sigurd@mh-hannover.de

S. Lortz

Integrated Research and Treatment Center Transplantation, IFB-Tx, Hannover Medical School, Hannover, Germany inflammatory cytokines and hypoxia than CytoCat and control cells.

Conclusions/interpretation The results demonstrate that an improved antioxidative defence status of insulin-secreting cells allowing efficient $\mathrm{H}_{2} \mathrm{O}_{2}$ inactivation is not incompatible with proper insulin secretory responsiveness to glucose stimulation and provide no support for a signalling role of $\mathrm{H}_{2} \mathrm{O}_{2}$ in insulin-secreting cells. Interestingly, the results also document for the first time that the decreased ROS formation with increasing glucose concentrations is of mitochondrial origin.

Keywords Catalase - Glucose-stimulated insulin secretion · Insulin-secreting cells · Pro-inflammatory cytokines ·

Reactive oxygen species

$\begin{array}{ll}\text { Abbreviations } \\ \mathrm{C}_{\mathrm{t}} & \text { Cycle threshold } \\ \text { CytoCat } & \text { Cytosolic catalase } \\ \text { DCFDA- } \mathrm{H}_{2} & \text { Dichlorodihydrofluorescein diacetate } \\ \text { DNP } & \text { 2,4-Dinitrophenol } \\ \text { ECM } & \text { Extracellular matrix } \\ \text { GSIS } & \text { Glucose-stimulated insulin secretion } \\ \text { MitoCat } & \text { Mitochondrial catalase } \\ \text { MTT } & \text { 3-(4,5-Dimethylthiazol-2-yl)-2,5- } \\ & \text { diphenyltetrazolium bromide } \\ \text { ROS } & \text { Reactive oxygen species } \\ \text { UCP2 } & \text { Uncoupling protein 2 }\end{array}$

\section{Introduction}

Pancreatic beta cells are characterised by their very low levels of the hydrogen peroxide $\left(\mathrm{H}_{2} \mathrm{O}_{2}\right)$-inactivating enzymes catalase and glutathione peroxidase despite adequate expression of the superoxide $\left(\mathrm{O}_{2}{ }^{-}\right)$-inactivating 
superoxide dismutases $[1,2]$. This imbalance results in beta cells having a high susceptibility to the toxicity of $\mathrm{H}_{2} \mathrm{O}_{2}$ and other reactive species (ROS) derived from it [3]. The extraordinary vulnerability of beta cells to ROS can explain a major part of pro-inflammatory cytokine toxicity resulting in the specific destruction of beta cells during type 1 diabetes [4]. The underlying reason for this lack of protection of beta cells against ROS toxicity is not yet clear. A possible reason might be that $\mathrm{H}_{2} \mathrm{O}_{2}$-inactivating enzymes interfere with physiological beta cell function. Genes associated with such an interfering effect have been termed 'disallowed genes' [5] and include $H k 1$ [6], the lactate dehydrogenase isoform Ldha and the monocarboxylate transporter Mct1 [7-10]. Expression of these genes in beta cells interferes with the normal control of insulin secretion by the physiological stimulus glucose, resulting in inappropriate insulin release (e.g. after physical exercise or in the fasted state) [11]. Cat mRNA was also found to be selectively repressed in mouse islets as compared with a large tissue panel $[8,12]$. A high expression level of $\mathrm{H}_{2} \mathrm{O}_{2}$-inactivating enzymes could potentially be detrimental for proper beta cell function. If so, a rapid dismutation of $\mathrm{H}_{2} \mathrm{O}_{2}$ through an efficient inactivating enzyme would interfere with beta cell metabolism, most likely manifesting as an impaired glucosestimulated insulin secretion (GSIS).

This idea has been taken up by the hypothesis that $\mathrm{H}_{2} \mathrm{O}_{2}$, as a relatively stable and freely diffusible molecule, might serve as an intracellular second messenger for GSIS in the beta cell $[13,14]$. Thus, high expression levels of the $\mathrm{H}_{2} \mathrm{O}_{2}$-inactivating enzymes catalase and glutathione peroxidase might interfere with the appropriate physiological insulin secretory response to rising postprandial glucose concentrations [13, 14]. Contrary to this idea it was hypothesised that further reduction of glutathione peroxidase enzyme activity at low glucose concentrations due to low cellular NADPH content can lead to $\mathrm{H}_{2} \mathrm{O}_{2}$ accumulation, which might prevent inappropriate insulin release [12].

It was therefore the aim of this study to elucidate whether an increase of the enzymatic $\mathrm{H}_{2} \mathrm{O}_{2}$ inactivation capacity through catalase overexpression in mitochondria or in the cytosol of insulin-secreting cells can protect against the toxicity of cytokines and hypoxia, without concomitantly disturbing insulin secretion in response to the physiological stimulus glucose.

\section{Methods}

Tissue culture of INS-1E cells Insulin-secreting INS-1E cells (kindly provided by C. Wollheim, University of Geneva Medical Center, Geneva, Switzerland) were cultured as previously described [15].
Islet isolation and single-cell preparation Pancreatic islets were isolated from $250-300 \mathrm{~g}$ adult male Lewis rats (Charles River, Sulzfeld, Germany) by collagenase digestion and handpicked under a stereo microscope. Thereafter, 70-100 uniformly sized isolated islets were cultured on extracellular matrix (ECM)-coated plates $(35 \mathrm{~mm})$ (Novamed, Jerusalem, Israel) in RPMI-1640 medium containing $5 \mathrm{mmol} / 1$ glucose, $10 \%$ FCS, penicillin and streptomycin at $37^{\circ} \mathrm{C}$ in a humidified atmosphere of $5 \% \mathrm{CO}_{2}$ as described earlier in detail [16]. Islets were cultured for 7 10 days on ECM plates to adhere and spread before they were lentivirally transduced and subsequently incubated with pro-inflammatory cytokines or used for insulin secretion studies. All animal procedures were conducted in accordance with the Principles of Laboratory Care.

Preparation of lentiviruses To overexpress the hydrogen peroxide-inactivating enzyme catalase in the cytosol (CytoCat) or in mitochondria (MitoCat) of INS-1E cells and rat islet cells, the cDNA of this enzyme $[17,18]$ was subcloned into the pLenti6/V5-MCS vector by standard molecular techniques. Lentiviral particles were prepared according to [19] and the virus titres were quantified as described elsewhere [20].

Lentiviral transduction INS-1E cells were separately infected with one of the constructs at a multiplicity of infection (MOI) of 10 for $2 \mathrm{~h}$. Thereafter the culture medium was changed. After an additional $24 \mathrm{~h}$ the cells were selected for catalase expression by blasticidin $(1 \mu \mathrm{mol} / \mathrm{l})$. The selected cells represented a mixed cell population. In contrast to single-cell clones the use of these cells should avoid clonal selection artefacts. Successful catalase overexpression was verified by western blot analyses and catalase activity measurement as previously described [17]. Islet cells were transduced on ECM-coated plates in the same way as INS-1E cells. After transduction the cells were kept in culture under control conditions for an additional $72 \mathrm{~h}$ for appropriate catalase expression.

Measurement of insulin secretion INS-1E cells were seeded in six-well plates at a density of $0.5 \times 10^{6}$ cells and grown for $48 \mathrm{~h}$. Then the cells were incubated for $1 \mathrm{~h}$ in bicarbonatebuffered Krebs-Ringer solution without glucose, supplemented with $0.1 \%$ albumin, and thereafter stimulated for $1 \mathrm{~h}$ with 3,10 , or $30 \mathrm{mmol} / \mathrm{l}$ glucose. After the incubation, the medium was removed and gently centrifuged to remove detached cells. Secreted insulin in the supernatant fraction was determined by radioimmunoassay using rat insulin as standard and the resulting values were normalised to DNA content. Primary islets were pre-incubated on ECM-coated plates for $1 \mathrm{~h}$ in bicarbonate-buffered Krebs-Ringer solution without glucose, supplemented with $0.1 \%$ albumin. Thereafter 
the cells were trypsinised, centrifuged, resuspended and incubated in Krebs-Ringer solution containing 3, 10 or $30 \mathrm{mmol} /$ 1 glucose for $1 \mathrm{~h}$. As for the INS-1E cells, the supernatant fraction was used for quantification of secreted insulin and the obtained values were normalised to DNA content.

Incubation of INS-1E cells with 2,4-dinitrophenol For mild uncoupling of the mitochondrial membrane potential, INS$1 \mathrm{E}$ cells were incubated with $25 \mu \mathrm{mol} / 1$ 2,4-dinitrophenol (DNP). Either the mitochondrial membrane potential was quantified by the use of rhodamine-123 or insulin secretion was quantified by RIA in the presence of DNP.

Measurement of cell viability after cytokine exposure and hypoxia For 3-(4,5-dimethylthiazol-2-yl)-2,5-diphenyltetrazolium bromide (MTT) assays 15,000 control and overexpressing INS-1E cells were seeded per well in $100 \mu \mathrm{l}$ culture medium in 96-well microplates and allowed to attach for $24 \mathrm{~h}$. Thereafter the cells were incubated for $72 \mathrm{~h}$ with 60 or $600 \mathrm{U} / \mathrm{ml}$ human IL-1 $\beta$ (PromoCell, Heidelberg, Germany) or a cytokine combination containing $60 \mathrm{U} / \mathrm{ml} \mathrm{IL-1} \beta$, $185 \mathrm{U} / \mathrm{ml}$ human TNF- $\alpha$ and $14 \mathrm{U} / \mathrm{ml}$ rat IFN- $\gamma$ (PromoCell). For incubation under hypoxic conditions the cells were incubated with $1 \% \mathrm{O}_{2}$ balanced with $\mathrm{N}_{2}$ for hypoxia. Hypoxia was generated in an oxygen-regulated incubator (CB210 incubator with $\mathrm{O}_{2}$ control option; Binder, Tuttlingen, Germany). After incubation, the viability of the cells was determined by the MTT assay as described earlier [17]. Viability was expressed as per cent of untreated cells. The viability under control conditions and the absolute optical density $\left(\mathrm{OD}_{550}\right)$ absorbance rates measured with the MTT assay were not significantly different between the control and overexpressing INS-1E cell clones, indicating that the cells showed no significant differences in metabolism, proliferation or basal viability.

Flow cytometric quantification of caspase-3 activation Caspase-3 activation was determined with the CaspGLOW fluorescein active caspase-3 staining kit (PromoCell). Control, CytoCat and MitoCat overexpressing INS-1E cells were seeded at a density of $1 \times 10^{6}$ cells per well of a six-well-plate and allowed to attach for $48 \mathrm{~h}$ before incubation with the indicated cytokines. Islet cells were incubated after lentiviral infection on ECM-coated plates with the indicated cytokines for $24 \mathrm{~h}$. After cytokine treatment INS-1E and islet cells were trypsinised and collected by centrifugation at $700 \mathrm{~g}$ for $5 \mathrm{~min}$. Caspase-3 activation was quantified according to the manufacturer's protocol as previously described [4].

Real-time quantitative RT-PCR Total RNA was isolated as previously described [21]. For cDNA synthesis, random hexamers were used to prime the reaction of the RevertAid $\mathrm{H}$ Minus M-MuLV reverse transcriptase (Fermentas, St
Leon-Rot, Germany). QuantiTect SYBR Green technology (Qiagen, Hilden, Germany), which uses a fluorescent dye that binds only double-stranded DNA, was employed. The reactions were performed using the Opticon Realtime-PCRSystem (BioRad, Hercules, CA, USA). Samples were first denatured at $94^{\circ} \mathrm{C}$ for 3 min followed by 40 PCR cycles comprised of a melting step at $94^{\circ} \mathrm{C}$ for $30 \mathrm{~s}$, an annealing step at $62^{\circ} \mathrm{C}$ for $30 \mathrm{~s}$ and an extension step at $72^{\circ} \mathrm{C}$ for $30 \mathrm{~s}$. The optimal variables for the PCR reactions were empirically defined and the purity and specificity of the amplified PCR product in each experiment was verified by melting curve analysis. All transcripts showed cycle threshold $\left(\mathrm{C}_{\mathrm{t}}\right)^{-}$ values that were at least ten $\mathrm{C}_{\mathrm{t}}$-values lower than the blank values. Each PCR amplification was performed in triplicate. The primer sequences are listed in electronic supplementary material (ESM) Table 1. Data are expressed as relative gene expression after normalisation to the housekeeping gene $\beta$ actin using the Qgene96 and LineRegPCR 12.13 software (http://www.gene-quantification.de/download.html).

Measurement of the mitochondrial membrane potential Forty-thousand cells were seeded onto black 96-well plates and allowed to attach for $24 \mathrm{~h}$. Thereafter cells were incubated with the indicated glucose concentrations followed by a $20 \mathrm{~min}$ incubation with $50 \mu \mathrm{mol} / 1$ rhodamine-123 (Life Technologies, Darmstadt, Germany) before the plates were washed and the rhodamine-123 fluorescence was quantified at $480 / 520 \mathrm{~nm}$ excitation/emission using the Victor $^{2} 1420$ Multilabel Counter (Perkin Elmer, Fremont, CA, USA).

Determination of oxidative stress using dichlorodihydrofluorescein diacetate For the detection of the overall oxidative stress, 40,000 cells were seeded onto black 96-well plates and cultured for $24 \mathrm{~h}$. Then the cells were pre-incubated with $10 \mu \mathrm{mol} / 1$ dichlorodihydrofluorescein diacetate (DCFDA$\mathrm{H}_{2}$; Life Technologies, Darmstadt, Germany) for $40 \mathrm{~min}$ at $37^{\circ} \mathrm{C}$. The medium containing the chemical was discarded and fresh medium with the indicated glucose concentrations was added. After incubation for $24 \mathrm{~h}$, the plates were analysed at $480 / 520 \mathrm{~nm}$ excitation/emission using the Victor $^{2}$ 1420 Multilabel Counter.

Detection of ROS by the use of DCFDA- $\mathrm{H}_{2}$ is dependent on its oxidation to the stable fluorescent derivative dichlorofluorescein and its subsequent accumulation in the cell. To detect clear differences between the different glucose concentrations and the cell clones an incubation time of $24 \mathrm{~h}$ was necessary. The data were expressed as the percentage of ROS formation in INS-1E control cells at $3 \mathrm{mmol} / \mathrm{l}$ glucose.

Statistical analyses Data are expressed as mean values \pm SEM. Statistical analyses were performed with GraphPad Prism 5 software (GraphPad, San Diego, CA, USA) using ANOVA plus Bonferroni test for multiple comparisons. 


\section{Results}

Effect of the hydrogen peroxide-inactivating enzyme catalase on glucose-induced insulin secretion in INS-1E and islet cells After validation of successful catalase overexpression and significant increase in catalase activity (ESM Fig. 1), the effects of lentivirus-induced overexpression of the hydrogen peroxide-inactivating enzyme catalase on glucoseinduced insulin secretion were investigated. INS-1E control cells showed at $3 \mathrm{mmol} / \mathrm{l}$ glucose a basal insulin secretion rate of approximately $0.26 \mathrm{ng}$ insulin $(\mu \mathrm{g} \mathrm{DNA})^{-1} \mathrm{~h}^{-1}$ (Fig. 1a). At 10 and $30 \mathrm{mmol} / 1$ glucose, insulin secretion of INS-1E control cells was increased about three- and fivefold, respectively. Basal (3 mmol/l glucose) and glucose-induced (10 and $30 \mathrm{mmol} / \mathrm{l}$ glucose) insulin secretion in both the cytosolic and mitochondrial overexpressing catalase INS-1E cell clones, showed no significant difference when compared with control cells (Fig. 1a). Cytosolic or mitochondrial catalase overexpression in INS-1E cells also did not significantly affect insulin content at any glucose concentrations (data not shown).

Rat islet cells lentivirally transduced with the CytoCat or MitoCat construct exhibited a basal insulin secretion rate of 3.0-3.3 ng insulin ( $\mu$ g DNA) $)^{-1} \mathrm{~h}^{-1}$ (Fig. $1 \mathrm{~b}$ ) at $3 \mathrm{mmol} / \mathrm{l}$ glucose. This insulin secretion was approximately increased threefold at $10 \mathrm{mmol} / \mathrm{l}$ and fivefold at $30 \mathrm{mmol} / \mathrm{l}$ glucose. At all three glucose concentrations, respectively, there was no significant difference between the catalase transduced and the control cells (Fig. 1b).

Effect of pro-inflammatory cytokines on cell viability and caspase-3 activation of catalase-overexpressing INS- $1 E$ cells Incubation of INS-1E control cells with $60 \mathrm{U} / \mathrm{ml}$ IL$1 \beta$ for $72 \mathrm{~h}$ reduced the viability of INS-1E control cells by approximately $30 \%$ (Fig. 2a). Increasing the IL- $1 \beta$ concentration to $600 \mathrm{U} / \mathrm{ml}$ raised the loss of viability to approximately $50 \%$ (Fig. 2a) and exposure to the cytokine mixture, containing $60 \mathrm{U} / \mathrm{ml} \mathrm{IL}-1 \beta, 185 \mathrm{U} / \mathrm{ml} \mathrm{TNF}-\alpha$ and $14 \mathrm{U} / \mathrm{ml}$ IFN- $\gamma$ caused a decrease of $90 \%$.

In CytoCat and MitoCat overexpressing cells the treatment with $60 \mathrm{U} / \mathrm{ml}$ IL-1 $\beta$ alone caused a mild $20 \%$ viability reduction, which was less than in INS-1E control cells (Fig. 2a). In both catalase overexpressing cell clones treatment with a ten-times higher IL- $1 \beta$ concentration caused higher toxicity. In MitoCat INS-1E cells $600 \mathrm{U} / \mathrm{ml} \mathrm{IL}-1 \beta$ reduced the viability by $35 \%$, which was significantly less than in equally treated INS-1E control cells (Fig. 2a), whereas cytosolic overexpression of catalase did not significantly protect against the toxicity of IL- $1 \beta$. MitoCat overexpression also significantly reduced the toxicity induced by the cytokine mixture, while CytoCat overexpression again did not significantly increase viability after exposure to the cytokine mixture. To evaluate whether the observed viability reduction was caused by apoptosis, the activation of caspase-3 after cytokine treatment of INS-1E cells was quantified. Both control and CytoCat transfected cells showed a marked increase in caspase3 activity (by $40 \%$ ) after incubation with 60 U IL-1 $\beta$ (Fig. 2b), and this was further enhanced by $600 \mathrm{U}$ IL-1 $\beta(80 \%)$ and the cytokine mixture (100\%) (Fig. 2b). The caspase-3 activation was significantly lower in MitoCat transfected INS-1E cells (60 U IL-1 $\beta$ : 4\%, 600 U IL-1 $\beta: 14 \%$ and cytokine mixture: $20 \%$, Fig. 2 b), indicating that the enhanced viability of MitoCat cells is caused by suppressed activation of apoptosis.

Effect of pro-inflammatory cytokines on caspase-3 activation of catalase-overexpressing islet cells Having demonstrated that MitoCat overexpression can provide protection against cytokine-induced apoptosis in insulin-secreting INS$1 \mathrm{E}$ cells, we next examined the impact of MitoCat overexpression on cytokine-activated apoptosis in primary rat

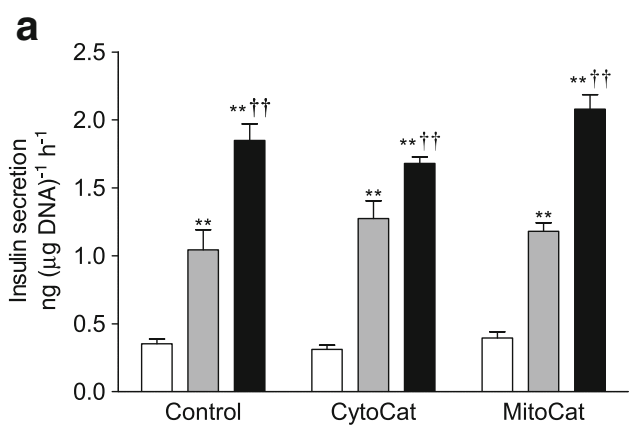

Fig. 1 Effect of cytoplasmic (CytoCat) and mitochondrial (MitoCat) catalase overexpression in insulin-secreting INS-1E and primary rat islet cells on insulin secretion. Insulin secretion was quantified after $1 \mathrm{~h}$ incubation with 3 (white bars), 10 (grey bars) and $30 \mathrm{mmol} / \mathrm{l}$ (black bars) glucose and normalised to the DNA content of the incubated cells. (a) INS-1E cells overexpressing cytosolically or mitochondrially located catalase and control cells were seeded $48 \mathrm{~h}$ before cells were incubated b

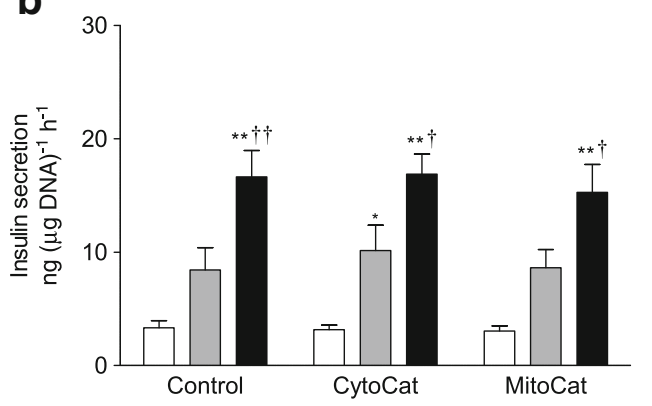

with different glucose concentrations. (b) Primary rat islet cells were lentivirally transduced to overexpress cytosolically or mitochondrially located catalase $72 \mathrm{~h}$ before the cells were incubated with different glucose concentrations. Data are means \pm SEM from six to nine (INS-1E cells) or seven to 12 (islet cells) individual experiments. ${ }^{*} p<0.05,{ }^{*} p<0.01$ compared with cells of the same clone at $3 \mathrm{mmol} / 1$ glucose; ${ }^{\dagger} p<0.05$, ${ }^{\dagger \dagger} p<0.01$ compared with cells of the same clone at $10 \mathrm{mmol} / 1$ glucose 


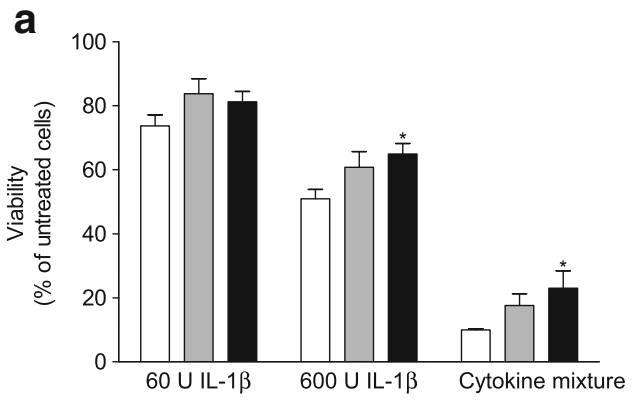

Fig. 2 Effect of cytoplasmic and mitochondrial catalase overexpression on the toxicity of pro-inflammatory cytokines in insulin-secreting INS-1E cells. INS-1E cells overexpressing cytosolically (grey bars) or mitochondrially (black bars) located catalase and control cells (white bars) were incubated with IL-1 $\beta$ (60 or $600 \mathrm{U} / \mathrm{ml}$ ) alone or a cytokine mixture $(60 \mathrm{U} / \mathrm{ml} \mathrm{IL}-1 \beta, 185 \mathrm{U} / \mathrm{ml} \mathrm{TNF}-\alpha, 14 \mathrm{U} / \mathrm{ml} \mathrm{IFN}-\gamma)$. (a)

islet cells. Incubation of islet cells with $600 \mathrm{U} / \mathrm{ml} \mathrm{IL}-1 \beta$ for $24 \mathrm{~h}$ induced caspase- 3 activity in control and CytoCat transfected cells by approximately $90 \%$ and the cytokine mixture further accelerated this increase up to $220 \%$ (Fig. 3). Consistent with the results in INS-1E cells, the increase in capase-3 activation was significantly attenuated in MitoCat overexpressing islet cells after incubation with pro-inflammatory cytokines (Fig. 3). IL-1 $\beta$ and the cytokine mixture elevated caspase- 3 activity only by 15 and $30 \%$, respectively, demonstrating that the protection of MitoCat transfected INS-1E cells could be reproduced in primary rat islet cells.

Effect of hypoxia on the cell viability of catalase- overexpressing INS-1E cells To investigate whether mitochondrially located catalase is able to prevent the deleterious effects of hypoxia, INS-1E control and MitoCat overexpressing cells were cultured for up to $72 \mathrm{~h}$ in the presence of $1 \% \mathrm{O}_{2}$ (hypoxia) and at the physiological concentration of $21 \% \mathrm{O}_{2}$ (normoxia). This hypoxic treatment of INS-1E control cells resulted in a time-dependent reduction in viability. After 24 and $48 \mathrm{~h}$

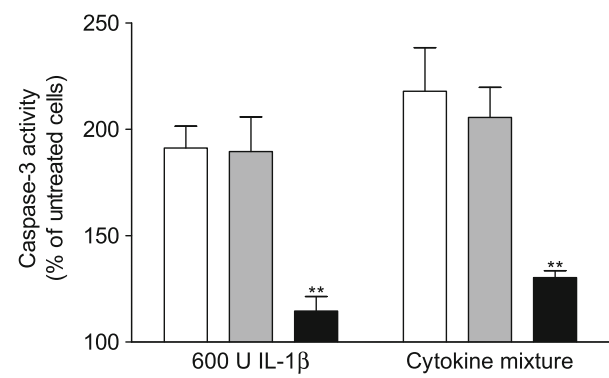

Fig. 3 Effect of cytoplasmic and mitochondrial catalase overexpression on cytokine-induced caspase-3 activation in primary rat islet cells. Islet cells overexpressing cytosolically (grey bars) or mitochondrially (black bars) located catalase and control cells (white bars) were incubated for $24 \mathrm{~h}$ with IL-1 $\beta(600 \mathrm{U} / \mathrm{ml})$ alone or a cytokine mixture $(60 \mathrm{U} / \mathrm{ml} \mathrm{IL}-1 \beta, 185 \mathrm{U} / \mathrm{ml}$ TNF- $\alpha, 14 \mathrm{U} / \mathrm{ml}$ IFN- $\gamma$ ). Caspase-3 activation was determined after $24 \mathrm{~h}$ cytokine incubation by flow cytometry and expressed as $\%$ of untreated cells. Data are means \pm SEM from four cytokine incubations. ${ }^{* *} p<0.01$ compared with control cells

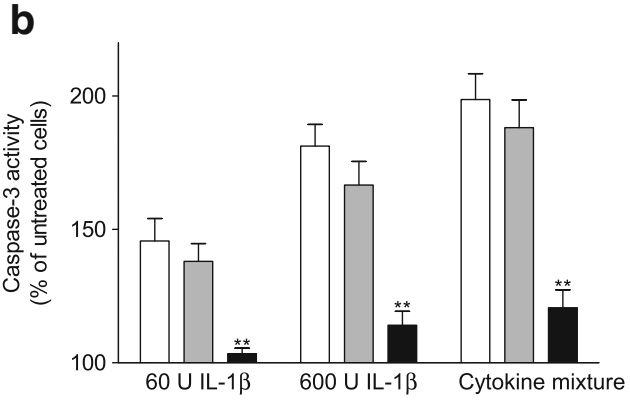

Viability of the cells was determined after $72 \mathrm{~h}$ cytokine incubation by the MTT assay and expressed as \% of the untreated cells. (b) Caspase- 3 activation was determined after $24 \mathrm{~h}$ cytokine incubation by flow cytometry and expressed as \% of untreated cells. Data are means \pm SEM from six to eight cytokine incubations. ${ }^{*} p<0.05$, $* * p<0.01$ compared with control cells

hypoxia viability was reduced by approximately $50 \%$ and after $72 \mathrm{~h}$ by $75 \%$ (Fig. 4). To mimic a transient hypoxic period, INS-1E cells were incubated for $24 \mathrm{~h}$ under hypoxia, followed by another $24 \mathrm{~h}$ incubation period under normoxic conditions. Under this experimental condition INS-1E cells showed a viability of $72 \%$, indicating a partial recovery compared with the viability loss after a $24 \mathrm{~h}$ hypoxic incubation. In contrast to control cells, reduction in viability of MitoCat overexpressing INS-1E cells was negligible after $24 \mathrm{~h}$ and $48 \mathrm{~h}$ of hypoxia. After $72 \mathrm{~h}$ of hypoxia the reduction in viability of MitoCat cells was significant (30\%) but threefold lower than in INS-1E control cells. Short-term hypoxia followed by normoxia ( $24 \mathrm{~h}$ hypoxia then $24 \mathrm{~h}$ normoxia) was without a significant effect on the viability of the MitoCat INS-1E cells (Fig. 4). Viability of control and transfected INS$1 \mathrm{E}$ cells was not significantly different under control conditions, indicating that catalase overexpression had no effect on basic viability (data not shown).

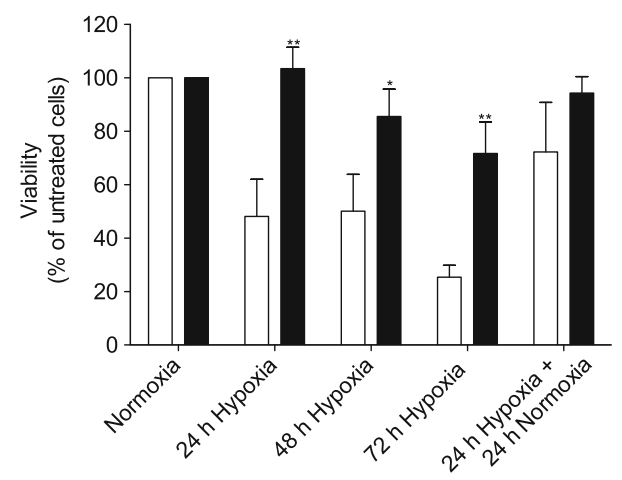

Fig. 4 Effect of mitochondrial catalase overexpression on the toxicity of hypoxia in insulin-secreting INS-1E cells. INS-1E cells overexpressing mitochondrially (black bars) located catalase and control cells (white bars) were incubated for up to $72 \mathrm{~h}$ with $1 \% \mathrm{O}_{2}$ or for $24 \mathrm{~h}$ under hypoxic conditions followed by $24 \mathrm{~h}$ incubation under control conditions. Viability of the cells was determined after hypoxic incubation by the MTT assay and expressed as $\%$ of untreated cells. Data are means \pm SEM from four or five individual experiments. ${ }^{*} p<0.05$, ${ }^{* *} p<$ 0.01 compared with control cells 


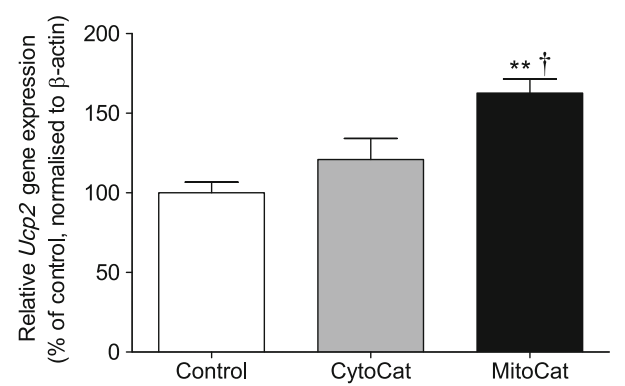

Fig. 5 Effect of cytoplasmic (CytoCat) and mitochondrial (MitoCat) catalase overexpression in insulin-secreting INS-1E cells on Ucp 2 gene expression. Total RNA was isolated $24 \mathrm{~h}$ after cell seeding from INS$1 \mathrm{E}$ cells overexpressing cytosolically (grey bar) or mitochondrially (black bar) located catalase and from control cells (white bar) and analysed by real-time quantitative RT-PCR with Ucp 2 specific primers. The $U p c 2$ expression levels were normalised to the housekeeping gene $\beta$-actin and the expression level of Ucp 2 in control cells was set as $100 \%$. Data are means \pm SEM from five to 12 individual experiments. ${ }^{* *} p<0.01$ compared with control cells; ${ }^{\dagger} p<0.05$ compared with CytoCat cells

Effect of catalase overexpression on Ucp2 gene expression in INS-1E cells Uncoupling protein 2 (UCP2), the isoform expressed in insulin-secreting cells, has the ability to reduce the generation of mitochondrial ROS by uncoupling of the proton motive force. To test whether the overexpression of catalase in INS-1E cells affects the expression of UCP2 and thereby the mitochondrial membrane potential, Ucp2 gene expression in control and catalase-overexpressing INS-1E cells was analysed by real-time quantitative RT-PCR. Mitochondrial catalase overexpression induced $U c p 2$ gene expression significantly by $60 \%$, while in CytoCat INS-1E cells Ucp 2 expression was not significantly changed $\left(120 \% U_{c p} 2\right.$ expression of control cells) (Fig. 5).

\section{Effect of catalase overexpression on mitochondrial membrane} potential in INS-1E cells To study the influence of catalase overexpression on mitochondrial membrane potential in INS-1E cells, changes in the mitochondrial membrane potential were quantified by rhodamine- 123 fluorescence at different glucose concentrations. The relative mitochondrial membrane potential of INS-1E control cells was not significantly increased by either 3 or $10 \mathrm{mmol} / 1$ glucose as compared with $0 \mathrm{mmol} / \mathrm{l}$ glucose (Fig. 6). Increasing the glucose concentration to $30 \mathrm{mmol} / \mathrm{l}$ significantly increased the mitochondrial membrane potential by more than $50 \%$ (Fig. 6). Catalase overexpression in INS-1E cells did not affect mitochondrial membrane potential at 3 or $10 \mathrm{mmol} / 1$ glucose when compared with $0 \mathrm{mmol} / \mathrm{l}$. Increasing the glucose concentration to $30 \mathrm{mmol} / \mathrm{l}$ increased the membrane potential of CytoCat INS-1E cells slightly but not significantly (plus 20\%) (Fig. 6). In MitoCat INS-1E cells this enhancing effect of increasing glucose concentrations on the mitochondrial membrane potential was not observed. Rather, at $30 \mathrm{mmol} / \mathrm{l}$ glucose, a significant reduction in the mitochondrial membrane potential was observed (compared with control cells at $30 \mathrm{mmol} / \mathrm{l}$, Fig. 6).

Effect of catalase on glucose-induced oxidative stress in INS-1E cells ROS formation in INS-1E control cells exposed to 10 and $30 \mathrm{mmol} / 1$ glucose was significantly decreased by 30 and $45 \%$, respectively, when compared with $3 \mathrm{mmol} / 1$ glucose (Fig. 7). Mitochondrial catalase overexpression reduced basal ROS formation at $3 \mathrm{mmol} / \mathrm{l}$ glucose significantly by $40 \%$ (Fig. 7); elevation of the glucose concentration to 10 and $30 \mathrm{mmol} / \mathrm{l}$ resulted in a further decrease in ROS formation. Compared with control cells the ROS concentrations were significantly lower in MitoCat cells at all three investigated glucose concentrations (Fig. 7). In CytoCat INS-1E cells, on the other hand, ROS formation was not significantly affected by $3 \mathrm{mmol} / \mathrm{l}$ glucose, although increasing glucose concentrations resulted in an analogous suppression of ROS generation in this cell clone (Fig. 7).

\section{Discussion}

Pro-inflammatory cytokines are important mediators of beta cell death during the development of type 1 diabetes mellitus [22, 23]. Likewise, after islet transplantation, when hypoxic conditions prevail at the site of implantation, proinflammatory mediators play an important role in the destruction of the transplanted beta cells [24, 25]. Pancreatic beta cells are extraordinarily vulnerable [3] and the reason for the weak protection against oxidative stress is their low antioxidative defence equipment $[1,2]$.

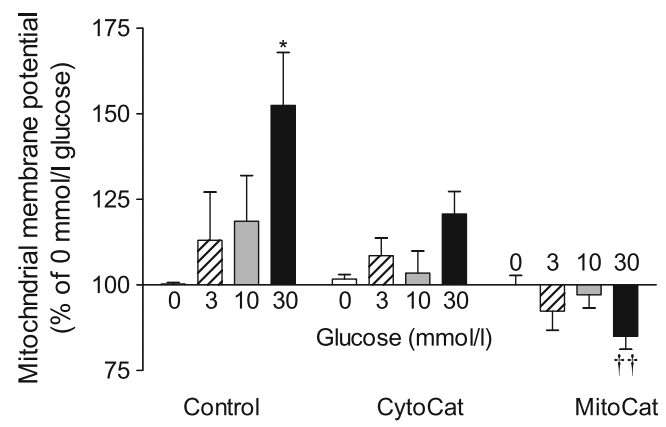

Fig. 6 Effect of cytoplasmic (CytoCat) and mitochondrial (MitoCat) catalase overexpression in insulin-secreting INS-1E cells on mitochondrial membrane potential. Changes in the rhodamine-123 fluorescence as an indicator for the mitochondrial membrane potential was measured in INS-1E cells overexpressing cytosolically or mitochondrially located catalase and in control cells by rhodamine- 123 fluorescence. The cells were incubated with 0 (white bars), 3 (hatched bars), 10 (grey bars) and $30 \mathrm{mmol} / 1$ (black bars) glucose, labelled with rhodamine-123 and analysed by flow cytometry. The mitochondrial membrane potential of each cell clone at $0 \mathrm{mmol} / 1$ glucose was set as $100 \%$. Data are means \pm SEM from seven to 15 individual experiments. ${ }^{*} p<0.05$ compared with cells of the same clone at $0 \mathrm{mmol} / 1$ glucose; ${ }^{\dagger} p<0.01$ compared with control cells at the same glucose concentration 


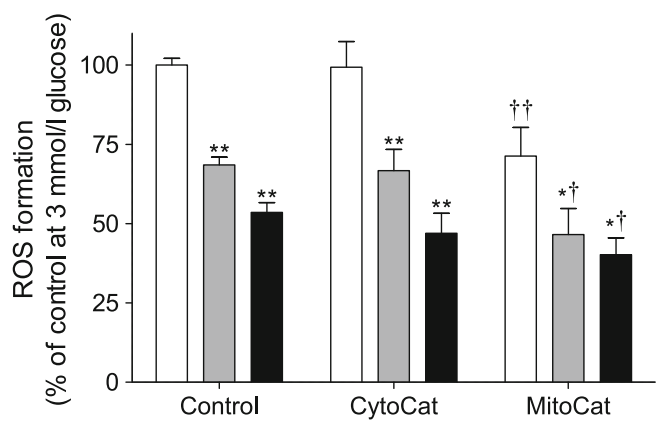

Fig. 7 Effect of cytoplasmic (CytoCat) and mitochondrial (MitoCat) catalase overexpression in insulin-secreting INS-1E cells on cellular oxidative stress. INS-1E cells overexpressing cytosolically or mitochondrially located catalase and control cells were seeded $24 \mathrm{~h}$ before cells were incubated with different glucose concentrations. Cellular oxidative stress was measured by the DCFDA- $\mathrm{H}_{2}$ oxidation assay after $24 \mathrm{~h}$ incubation with 3 (white bars), 10 (grey bars) and $30 \mathrm{mmol} / 1$ (black bars) glucose. The ROS formation in INS-1E control cells at $3 \mathrm{mmol} / 1$ glucose was set as $100 \%$. Data are means \pm SEM from 13-15 individual experiments. Each measurement was performed in triplicate. ${ }^{*} p<0.05,{ }^{* *} p<0.01$ compared with cells of the same clone at $3 \mathrm{mmol} / \mathrm{l}$ glucose; ${ }^{\dagger} p<0.05,{ }^{\dagger \dagger} p<0.01$ compared with control cells at the same glucose concentration

A potential approach to protect beta cells against cytokinemediated destruction by ROS is the beta cell-specific overexpression of the $\mathrm{H}_{2} \mathrm{O}_{2}$-inactivating enzyme catalase in mitochondria $[4,18]$. However, since the ability of beta cells to secrete insulin in a glucose-dependent manner is indispensable for efficient regulation of glucose homeostasis, this mechanism should remain undisturbed by any protection strategy for insulin-secreting cells.

In an earlier study using the RINm5F cell line we successfully documented the protective potential of mitochondrial catalase overexpression [18]. Although we were not able to draw a conclusion about the impact of catalase overexpression on the insulin secretory potential of glucose, since insulin release from this cell line is not responsive to glucose stimulation at physiological concentrations, no deleterious effects on cell proliferation, glucose oxidation or insulin content were observed [18]. Likewise, in studies on transgenic animals, no negative impact of catalase or glutathione peroxidase overexpression on insulin secretion and beta cell phenotype has been reported [26, 27]. However, since these studies focused on the protective role of ROS-inactivating enzymes, interactions between ROS and GSIS were not analysed.

Using the glucose-responsive INS-1E insulin-secreting cell line [15] and primary rat islet cells, we were able to show in the present study that overexpression of $\mathrm{H}_{2} \mathrm{O}_{2}$-inactivating catalase provides protection against cytokine-induced toxicity through suppression of intramitochondrial ROS formation. Thus mitochondrial catalase overexpression is not incompatible with the signalling function of mitochondrial metabolism in pancreatic beta cells. Catalase overexpressing INS-1E cells were protected not only against cytokine-induced toxicity but also against hypoxic stress as is the case after islet transplantation [28-30], when hypoxic conditions prevail at the site of implantation and, in conjunction with pro-inflammatory cytokines, mediate the destruction of the transplant [24, 25].

Therefore the very low levels of $\mathrm{H}_{2} \mathrm{O}_{2}$-inactivating enzymes, which make the pancreatic beta cells so extraordinarily vulnerable and sensitive to oxidative stress [3], is not a necessity in order for beta cells to maintain a proper physiological insulin secretory responsiveness to glucose stimulation, and higher levels of these enzymes would not be incompatible with this function. Thus, expression of $\mathrm{H}_{2} \mathrm{O}_{2}$ inactivating enzymes, such as catalase and glutathione peroxidase, cannot be considered to be forbidden [5] with respect to a potential incompatibility with proper insulin secretory responsiveness to physiological glucose stimulation. This is at variance with other weakly expressed proteins in beta cells, such as lactate dehydrogenase and the monocarboxylate transporter, whose presence has been shown to be incompatible with undisturbed beta cell function [7-10,12] and also even to be life threatening [11]. Therefore, mitochondrial catalase overexpression can be considered as a feasible therapeutic concept with the aim of protecting beta cells in islets isolated from the pancreas for subsequent transplantation to diabetic patients. This would protect against the particular stress to which the cells are exposed during the initial time after transplantation into liver and which can result in destruction of up to two-thirds of the transplanted cells [25] before proper supply of oxygen and nutrients is secured through restoration of full vascular supply in the implantation site [28-30]. Protection could also be provided against destruction by proinflammatory cytokines released from islet infiltrating immune cells during reoccurrence of the autoimmune attack against the transplanted islets in the recipient organism with type 1 diabetes, with its persisting autoimmunity [25, 31, 32].

In contrast to the overproduction of the $\mathrm{B}$ cell lymphoma (extra large) anti-apoptotic protein $\left(\mathrm{Bcl}_{\mathrm{XL}}\right)$ in islets [33], the overexpression of the $\mathrm{H}_{2} \mathrm{O}_{2}$-inactivating enzyme catalase in mitochondria did not blunt the physiological insulin secretory response to glucose. The intact secretory responsiveness was maintained although mitochondrial catalase overexpression caused mild uncoupling. This is likely to be the result of the increased Ucp2 expression found as a consequence of catalase overexpression in mitochondria.

It has been reported that a beta cell-specific knock out of Ucp2 was associated with increased mitochondrial membrane potential, ATP content and, subsequently, with elevated glucose-induced insulin secretion [34, 35]. Conversely, strong overexpression of UCP2 attenuated glucose-induced insulin secretion [36], thereby indicating that uncoupling of the proton flux by UCP2 has a negative effect on insulin secretory responsiveness. Data from studies investigating a common polymorphism in the $U c p 2$ promoter suggest that the level of $U c p 2$ expression correlates with the inhibition of glucose- 
induced insulin secretion [37]. In catalase overexpressing INS-1E cells, however, the slight elevation of the Ucp2 expression level caused only a mild decrease in the mitochondrial membrane potential and thus did not negatively affect glucose-induced insulin secretion at physiological glucose concentrations. CytoCat cells represent a transition situation between the control situation and the significant decrease in the membrane potential in MitoCat cells. A significant reduction in the membrane potential was observed only at supraphysiological glucose concentrations $(30 \mathrm{mmol} / \mathrm{l})$. Also a mild uncoupling of INS-1E control cells by DNP was not able to diminish glucose-induced insulin secretion in these cells (ESM Fig. 2). Both findings indicate that $U c p 2$ expression may have to exceed a certain threshold level before a negative effect on insulin secretion is observed.

A signalling role for $\mathrm{H}_{2} \mathrm{O}_{2}$ is established in plants [38] and has also been considered in various mammalian cell types [39, 40], including insulin-secreting cells [13, 14]. However, in our study overall cellular ROS formation was lower at higher glucose concentrations as has been reported by other groups [41-43] and in addition it was suppressed by MitoCat overexpression at all three investigated glucose concentrations. Both findings, together with the insulin secretion data of overexpressing cells, indicate that there is no supporting role for $\mathrm{H}_{2} \mathrm{O}_{2}$, especially mitochondrial $\mathrm{H}_{2} \mathrm{O}_{2}$, as an amplifying signalling molecule in the regulation of physiological insulin secretion. Moreover, the data do not support the concept of beta cell glucose toxicity, mediated by an increasing ROS formation along with increasing glucose concentrations [44, 45]. Rather, an increased mitochondrial metabolic flux through the respiratory chain at higher glucose concentrations goes along with a more efficient electron flux so that less electrons leave the mitochondrial respiratory chain prematurely at complexes 1 and 3 to form $\mathrm{O}_{2}{ }^{--}$and subsequently $\mathrm{H}_{2} \mathrm{O}_{2}$.

In summary, mitochondrial catalase overexpression to prevent $\mathrm{H}_{2} \mathrm{O}_{2}$ formation and free radical species derived from it, such as the particularly toxic hydroxyl radical [4], does not blunt the physiological insulin secretory response to glucose.

Funding This work was supported by a grant from the Federal Ministry of Education and Research (Integrated Research and Treatment Center for Transplantation, reference No. 01EO0802) and by the European Union (IMI JU IMIDIA IMI/115005 in the Framework Programme 7 [FP7] of the European-Community).

Duality of interest The authors declare that there is no duality of interest associated with this manuscript.

Contribution statement SLo, EG-C and ON contributed to the design, conduct, data analysis and manuscript preparation. SLe contributed to the planning, design, data analysis, manuscript preparation and support for the study. All authors approved the final manuscript.

\section{References}

1. Tiedge M, Lortz S, Drinkgern J, Lenzen S (1997) Relation between antioxidant enzyme gene expression and antioxidative defense status of insulin-producing cells. Diabetes 46:1733-1742

2. Lenzen S, Drinkgern J, Tiedge M (1996) Low antioxidant enzyme gene expression in pancreatic islets compared with various other mouse tissues. Free Radic Biol Med 20:463-466

3. Lenzen S (2008) Oxidative stress: the vulnerable beta-cell. Biochem Soc Trans 36:343-347

4. Gurgul-Convey E, Mehmeti I, Lortz S, Lenzen S (2011) Cytokine toxicity in insulin-producing cells is mediated by nitro-oxidative stress-induced hydroxyl radical formation in mitochondria. J Mol Med (Berl) 89:785-798

5. Quintens R, Hendrickx N, Lemaire K, Schuit F (2008) Why expression of some genes is disallowed in beta-cells. Biochem Soc Trans 36:300-305

6. Schuit F, de Vos A, Farfari S et al (1997) Metabolic fate of glucose in purified islet cells. Glucose-regulated anaplerosis in beta-cells. J Biol Chem 272:18572-18579

7. Alcazar O, Tiedge M, Lenzen S (2000) Importance of lactate dehydrogenase for the regulation of glycolytic flux and insulin secretion in insulin-producing cells. Biochem J 352(Pt 2):373-380

8. Thorrez L, Laudadio I, van Deun K et al (2011) Tissue-specific disallowance of housekeeping genes: the other face of cell differentiation. Genome Res 21:95-105

9. Sekine N, Cirulli V, Regazzi R et al (1994) Low lactate dehydrogenase and high mitochondrial glycerol phosphate dehydrogenase in pancreatic beta-cells. Potential role in nutrient sensing. J Biol Chem 269:4895-4902

10. Pullen TJ, Khan AM, Barton G, Butcher SA, Sun G, Rutter GA (2010) Identification of genes selectively disallowed in the pancreatic islet. Islets 2:89-95

11. Otonkoski T, Kaminen N, Ustinov J et al (2003) Physical exerciseinduced hyperinsulinemic hypoglycemia is an autosomal-dominant trait characterized by abnormal pyruvate-induced insulin release. Diabetes 52:199-204

12. Schuit F, van Lommel L, Granvik M et al (2012) $\beta$-Cell-specific gene repression: a mechanism to protect against inappropriate or maladjusted insulin secretion? Diabetes 61:969-975

13. Leloup C, Tourrel-Cuzin C, Magnan C et al (2009) Mitochondrial reactive oxygen species are obligatory signals for glucose-induced insulin secretion. Diabetes 58:673-681

14. Pi J, Bai Y, Zhang Q et al (2007) Reactive oxygen species as a signal in glucose-stimulated insulin secretion. Diabetes 56: 1783-1791

15. Asfari M, Janjic D, Meda P, Li G, Halban PA, Wollheim CB (1992) Establishment of 2-mercaptoethanol-dependent differentiated insulin-secreting cell lines. Endocrinology 130:167-178

16. Mehmeti I, Gurgul-Convey E, Lenzen S, Lortz S (2011) Induction of the intrinsic apoptosis pathway in insulin-secreting cells is dependent on oxidative damage of mitochondria but independent of caspase-12 activation. Biochim Biophys Acta 1813: $1827-1835$

17. Tiedge M, Lortz S, Munday R, Lenzen S (1998) Complementary action of antioxidant enzymes in the protection of bioengineered insulin-producing RINm5F cells against the toxicity of reactive oxygen species. Diabetes 47:1578-1585

18. Gurgul E, Lortz S, Tiedge M, Jörns A, Lenzen S (2004) Mitochondrial catalase overexpression protects insulin-producing cells against toxicity of reactive oxygen species and proinflammatory cytokines. Diabetes 53:2271-2280

19. Zufferey R, Dull T, Mandel RJ et al (1998) Self-inactivating lentivirus vector for safe and efficient in vivo gene delivery. $\mathrm{J}$ Virol 72:9873-9880 
20. Sastry L, Johnson T, Hobson MJ, Smucker B, Cornetta K (2002) Titering lentiviral vectors: comparison of DNA, RNA and marker expression methods. Gene Ther 9:1155-1162

21. Chomczynski P, Sacchi N (1987) Single-step method of RNA isolation by acid guanidinium thiocyanate-phenol-chloroform extraction. Anal Biochem 162:156-159

22. Eizirik DL, Mandrup-Poulsen T (2001) A choice of death - the signal-transduction of immune-mediated beta-cell apoptosis. Diabetologia 44:2115-2133

23. Cnop M, Welsh N, Jonas JC, Jörns A, Lenzen S, Eizirik DL (2005) Mechanisms of pancreatic beta-cell death in type 1 and type 2 diabetes: many differences, few similarities. Diabetes 54(Suppl 2): S97-S107

24. Monti P, Scirpoli M, Maffi P et al (2008) Islet transplantation in patients with autoimmune diabetes induces homeostatic cytokines that expand autoreactive memory T cells. J Clin Invest 118:1806-1814

25. Gibly RF, Graham JG, Luo X, Lowe WL Jr, Hering BJ, Shea LD (2011) Advancing islet transplantation: from engraftment to the immune response. Diabetologia 54:2494-2505

26. Harmon JS, Bogdani M, Parazzoli SD et al (2009) beta-Cellspecific overexpression of glutathione peroxidase preserves intranuclear MafA and reverses diabetes in $\mathrm{db} / \mathrm{db}$ mice. Endocrinology 150:4855-4862

27. Chen H, Li X, Epstein PN (2005) MnSOD and catalase transgenes demonstrate that protection of islets from oxidative stress does not alter cytokine toxicity. Diabetes 54:1437-1446

28. Lau J, Henriksnas J, Svensson J, Carlsson PO (2009) Oxygenation of islets and its role in transplantation. Curr Opin Organ Transplant 14:688-693

29. Carlsson PO, Palm F, Mattsson G (2002) Low revascularization of experimentally transplanted human pancreatic islets. J Clin Endocrinol Metab 87:5418-5423

30. Carlsson PO, Palm F (2002) Oxygen tension in isolated transplanted rat islets and in islets of rat whole-pancreas transplants. Transpl Int 15:581-585

31. Barshes NR, Wyllie S, Goss JA (2005) Inflammation-mediated dysfunction and apoptosis in pancreatic islet transplantation: implications for intrahepatic grafts. J Leukoc Biol 77:587-597

32. Balamurugan AN, Bottino R, Giannoukakis N, Smetanka C (2006) Prospective and challenges of islet transplantation for the therapy of autoimmune diabetes. Pancreas 32:231-243

33. Zhou YP, Pena JC, Roe MW et al (2000) Overexpression of Bcl-x (L) in beta-cells prevents cell death but impairs mitochondrial signal for insulin secretion. Am J Physiol Endocrinol Metab 278: E340-E351

34. Saleh MC, Wheeler MB, Chan CB (2002) Uncoupling protein-2: evidence for its function as a metabolic regulator. Diabetologia 45:174-187

35. Robson-Doucette CA, Sultan S, Allister EM et al (2011) Beta-cell uncoupling protein 2 regulates reactive oxygen species production, which influences both insulin and glucagon secretion. Diabetes 60:2710-2719

36. Chan CB, MacDonald PE, Saleh MC, Johns DC, Marban E, Wheeler MB (1999) Overexpression of uncoupling protein 2 inhibits glucose-stimulated insulin secretion from rat islets. Diabetes 48:1482-1486

37. Sesti G, Cardellini M, Marini MA et al (2003) A common polymorphism in the promoter of UCP2 contributes to the variation in insulin secretion in glucose-tolerant subjects. Diabetes 52:1280-1283

38. Noctor G, de Paepe R, Foyer CH (2007) Mitochondrial redox biology and homeostasis in plants. Trends Plant Sci 12:125-134

39. Queisser N, Fazeli G, Schupp N (2010) Superoxide anion and hydrogen peroxide-induced signaling and damage in angiotensin II and aldosterone action. Biol Chem 391:1265-1279

40. Rigoulet M, Yoboue ED, Devin A (2011) Mitochondrial ROS generation and its regulation: mechanisms involved in $\mathrm{H}(2) \mathrm{O}(2)$ signaling. Antioxid Redox Signal 14:459-468

41. Martens GA, Cai Y, Hinke S, Stange G, van de Casteele M, Pipeleers D (2005) Glucose suppresses superoxide generation in metabolically responsive pancreatic beta-cells. J Biol Chem 280:20389-20396

42. Martens G, Cai Y, Hinke S, Stange G, van de Casteele M, Pipeleers D (2005) Nutrient sensing in pancreatic beta-cells suppresses mitochondrial superoxide generation and its contribution to apoptosis. Biochem Soc Trans 33:300-301

43. Sarre A, Gabrielli J, Vial G, Leverve XM, AssimacopoulosJeannet F (2012) Reactive oxygen species are produced at low glucose and contribute to the activation of AMPK in insulinsecreting cells. Free Radic Biol Med 52:142-150

44. Brownlee M (2003) A radical explanation for glucose-induced beta-cell dysfunction. J Clin Invest 112:1788-1790

45. Robertson RP, Harmon J, Tran PO, Tanaka Y, Takahashi H (2003) Glucose toxicity in beta-cells: type 2 diabetes, good radicals gone bad, and the glutathione connection. Diabetes 52:581-587 